\title{
Валерія Фостікова
}

Київський національний університет імені Тараса Шевченка

\section{Сучасні вимоги до цифрових компетентностей державних службовців}

У статті проаналізовано сучасні вимоги до цифрових компетентностей державних службовців, які актуалізувалися в результаті запровадження моделі електронного урядування. Досліджено класифікацію компетенцій, розроблену С. Ганіусом (технічні, соціально-технічні, організаційні, управлінські та політико-адміністративні компетенції), підтверджено ії валідність загальноєвропейським соціологічним дослідженням Н. Огонека. Стверджується, що тенденція до підвищення цифрових кометентностей властива більшості розвинених країн і відображається у рекомендаціях ОЕСР, зокрема у документі «Посилення цифрового уряду» (2019), що передбачає формування нової цифрової культури серед державних службовців. У результаті прищеплення цієї культури відбудеться розширення повноважень, мислення та навичок.

Ключові слова: иифрровізаиія, компетенції, держсавний службовець, публічні послуги, онлайн, інформаційно-комунікаційні технології, державний сектор

\section{Modern requirements for digital competencies of civil servants}

\section{Valeriia Fostikova, Taras Shevchenko National University of Kyiv}

The article analyzes the current requirements for digital competencies of civil servants, which have become relevant as a result of the introduction of the e-government model. The classification of competencies developed by S. Hanius (technical, socio-technical, organizational, managerial and political-administrative competencies) is studied, its validity is confirmed by N. Ogonek's all-European sociological research. It is argued that the trend towards increasing digital competences is common to most developed countries and is reflected in the OECD recommendations, in particular in the document "Strengthening Digital Government" (2019), which provides for the formation of a new digital culture among civil servants. As a result of inculcating this culture, there will be an expansion of authority, thinking and skills.

Keywords: digitalization, competencies, civil servant, public services, online, information and communication technologies, public sector

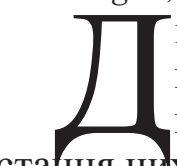

іджиталізація, як пул різноманітних соціально-технічних явищ та процесів впровадження та використання цих технологій у більш широкому індивідуальному, організаційному та суспільному контексті, надзвичайно змінює світ. Ці зміни стосуються як бізнесу (технологічні досягнення дозволяють підвищити ступінь автоматизації, систематизації тощо), так і публічної сфери. Для останньої цифровізація відкриває безліч потенційних вигод з точки зору економії витрат, підвищення ефективності, кращого надання послуг та більшої прозорості, готовності державних організацій надавати свої послуги онлайн.

«Сучасний етап розвитку суспільства характеризується всебічним і масовим впровадженням в усі сфери життя засобів інформаційних технологій, орієнтованих на збір, обробку, зберігання, передачу і поширення інформації. Інформація як головний атрибут постіндустріального інформаційного суспільства стає найважливішим стратегічним ресурсом, а технології роботи з інформацією сильною конкурентною перевагою, драйвером системи державного управління в умовах забезпечення інформаційної взаємодії громадян, бізнесу та державних структур. Перехід багатьох ключових функцій в інформаційний простір відкриває нові можливості підвищення якості державного управління» (Ермак, 2018).

Відповідно, для успішного використання цих можливостей виникає потреба у високоосвічених працівниках. Зростаюча важливість та розгортання інформаційних технологій, по суті, вимагають отримання державними службовцями цифрових компетенцій. Однак, через надзвичайно швидкий рух оцифровування та вимоги до роботи, що постійно змінюються, важливого значення набуває адаптивність та здатність до оперативного навчання.

Робота в державному секторі в силу своєї природи потребує розгалужених знань, оскільки державні службовці мають одночасно займатися організаційними, юридичними 
та адміністративними темами. 3 моменту запровадження на практиці електронного уряду цей аспект актуалізується ще більше, адже організаційні зміни та нові навички ідуть за цих умов у поєднанні з використанням інформаційно-комунікаційних технологій у державних адміністраціях.

Намагаючись класифікувати необхідні компетенції в контексті електронного уряду, С. Ганіус здійснив грунтовний огляд науково-дослідної літератури та визначив п'ять категорій компетенцій, якими мають володіти державні службовці в цифрову епоху. Це технічні, соціально-технічні, організаційні, управлінські та політико-адміністративні компетенції. Технічні компетенції - це всі навички, пов'язані з IT (основи, стратегія та дизайн інформаційних систем). Вимір соціально-технічних компетенцій стосується навичок, що знаходяться на межі між технічними системами та людьми, поєднуючи ïx, наприклад, ключові вимоги щодо впливу IT/електронного уряду. Організаційні компетенції стосуються організаційної інтеграції IT/електронного уряду, організаційних структур та управління процесами. Категорія управлінських компетенцій містить типові ділові та управлінські навички в галузі в контексті IT/електронного уряду, такі як управління проектами, змінами та фінансами. Остання категорія складається 3 політико-адміністративних компетенцій. Вона охоплює навички, що стосуються контексту, в якому працює IT/електронний уряд, таких як правові умови та політика. Ці п’ять категорій демонструють різноманітну та міждисциплінарну сферу електронного урядування, вимагаючи безлічі різних компетенцій, що виходять за межі простого IT-знання (Hunnius, 2015).

Н. Огонек вирішив перевірити ці категорії компетентностей, провівши загальноєвропейське опитування серед близько 700 представників державного сектору, яке виявило актуальність усіх п’яти категорій з акцентом на міждисциплінарному навчанні. Результати даного соціологічного дослідження показують, що необхідне глибоке розуміння надання державних послуг та інформаційно-комунікаційних технологій у поєднанні зі знаннями про організаційні процеси та політичні кон134 тексти, пов'язані з управлінськими компетенціями (Ogonek, 2016).

Одна 3 ключових рекомендацій 3 посилення електронного уряду, розроблених OECP, полягає у концентрації на розвитку цифрових та пов'язаних з даними навичок у державному секторі, створенні профілів та кар'єрних шляхів, заснованих на прогнозованих потребах, та наданні програм для підготовки та перепідготовки державних службовців (OECD, 2019). Це означає, що уряди повинні інвестувати у створення правильного середовища для державних секторів, які можуть ефективно працювати в епоху цифрових технологій. Це передбачає підтримку професіоналізації цифрових кар'єрних шляхів у державних секторах та розвиток передової культури державної служби, яка використовує цифрові технології для взаємодії 3 користувачами та робить задоволення потреб останніх центром своєї діяльності. Для цього необхідні спеціальні структури, які сприятимуть усвідомленню можливостей та переваг цифрових технологій, а також повторному використанню даних, оснащенню державних службовців необхідними навичками. Якщо цифрове перетворення державного сектору приведе до успішної моделі надання послуг, орієнтованої на користувачів, тоді воно асоціюватиметься 3 розширенням повноважень на державній службі, новим збагаченим мисленням і можливостями i, перш за все, адекватним керівництвом та цифровими навичками.

Практика багатьох розвинених країн доводить, що рекомендації, розроблені ОЕСР, не лишаються у теоретичній площині. Так, зокрема у Канаді колишній голова правління казначейства та міністр цифрового уряду Скотт Брісон оголосив про створення цифрової академії для федерального уряду. Канадська служба цифрових послуг також співпрацює з університетом Далхаузі, щоб провести аналіз потреб у навчанні цифровим технологіям федеральної державної служби.

Підвищення цифрових навичок державних службовців означає, що інновації будуть простішими, 3 кращою доставкою, кращими рішеннями щодо придбання та більшою впевненістю та готовністю співпрацювати між департаментами. Відповідно, будуть 
оптимізовані витрати часу та ресурсів, створено такий тип інтеграції, обміну та прозорості, який має вирішальне значення для досягнення пріоритетів. Підтримка виконавчої влади $є$ надзвичайно важливою, тому інтеграція «лідерства службовця» у підготовку керівних кадрів стане головним фактором розвитку культури та організаційного розвитку в державному секторі.

Авторський колектив на чолі з О. Васильєвою, досліджуючи розвиток цифрових компетенцій державних службовців, дійшли висновку про те, що серед інформаційно-комунікаційних навичок, якими має володіти робітник державного сектору, можна виокремити три основні групи: 1) загальні; 2) професійні та 3) комплементарні. Перша група компетенцій передбачає прості вміння, як-то користування Інтернетом, використання програм (Word, Excel тощо) для виконання поточних завдань. Друга - пов'язана з оперуванням і навіть виробництвом продуктів IKT, зокрема веб-сторінок, хмарних даних, управлінням мережами тощо. Третя група компетенцій асоціюється 3 використанням навичок, які допомагають у процесі виконання нових завдань, приміром, бізнес-планування, по- слуговування соціальними мережами для підтримки комунікації зі співробітниками та споживачами публічних послуг, просування власної продукції на електронних комерційних платформах і т. п. (Васильева, 2018).

Одночасно варто розуміти, що вимоги до цифрових компетенцій державних службовців, не означають, що кожен із них має стати дизайнером чи програмістом, a, скоріше, мати належне підгрунтя, щоб формувати спритний, чуйний, розширюваний, аполітичний, цілісний, орієнтований на цінності та участь, а також заснований на доказах суспільний сектор, незалежно від того, над чим працює кожен окремий публічний управлінець сьогодні. Найкращі приклади електронного урядування пов'язані, насамперед, із вагомими внутрішніми інвестиціями в людей, культуру, чіткі стратегії та цілі, а також внутрішні цифрові, технічні та дизайнерські можливості. Розвиток внутрішнього потенціалу 3 урахуванням передової та багаторазової цифрової публічної інфраструктури стане запорукою концентрації на потребах користувача, розробки якісних загальних та основних публічних сервісів.

\section{БІБЛІОГРАФІЧНІ ПОСИЛАННЯ}

Васильева, Е., Пуляева, В., \& Юдина, В. (2018). «Развитие цифровых компетенций государственных гражданских служащих Российской Федерации».

Ермак, А., \& Кутергина, Е. (2018), «ИКТ-компетенции в сфере государственного управления: вызовы современности». Відновлено з https://openbooks.itmo.ru/ru/file/8429/8429.pdf.

Hunnius, S., Paulowitsch, B., \& Schuppan, T. (2015), Does E-government Education Meet Competency Requirements? An Analysis of the German University System from International Perspective. Bui T.X., Sprague R.H. (Eds.). 48th Hawaii International Conference on System Sciences (HICSS), HI, USA, IEEE, Piscataway, NJ. (pp. 2116-2123).

OECD. (2019). Strengthening digital government. OECD Going Digital Policy Note. OECD. Paris. Retrieved from www.oecd.org/goingdigital/strengthening-digital-government.pdf.

Ogonek, N., Gorbacheva, E., Räckers, M., Becker, J., Krimmer, R., Broucker, B.,\& Crompvoets, J. (2016). Towards Efficient EGovernment. Identifying Important Competencies for EGovernment in European Public Administrations. Scholl, H. J. (Ed.). Electronic government and electronic participation: Joint proceedings of ongoing research., $\mathrm{PhD}$ papers, posters and workshops of IFIP EGOV and ePart 2016, Innovation and the public sector, IOS Press, Amsterdam, Berlin, Washing-ton, DC. (pp. 155-162). 